\title{
SÍMBOLOS Y RITUALES RELIGIOSOS EN EL ALJARAFE SEVILLANO
}

\author{
Salvador RODRÍGUEZ-BECERRA \\ Universidad de Sevilla \\ becerra@us.es
}

\section{SYMBOLS AND RELIGIOUS RITUALS IN ALJARAFE (SEVILLA)}

Resumen: Se señalan los aspectos más importantes de la religiosidad del Aljarafe, comarca natural muy definida y cercana a la ciudad de Sevilla con la que ha estado estrechamente relacionada históricamente y en la actualidad. Formada por numerosos pueblos municipios cada uno de ellos tiene sus propios símbolos religiosos e identitarios, a su vez ha estado marcada por la preponderancia de símbolos unificadores la Virgen de Loreto y la Virgen del Rocío. La primera, ligada originariamente a las villas de Espartinas y Umbrete, por senda leyendas de aparición, su devoción se expandió de la mano de los franciscanos observantes, instalados desde el siglo XVI en el convento-santuario de Loreto, que ha pretendido hacer de esta imagen la patrona efectiva de la comarca, aunque no lo han logrado plenamente. La Virgen del Rocío desde su santuario de Almonte ha ganado desde la segunda mitad del siglo pasado una poderosa influencia en la comarca, de suerte que la casi totalidad de los pueblos han creado una hermandad, encontrándose entre ellas algunas de las más señeras de las que acuden a la aldea en la fiesta de Pentecostés.

Abstract: The most important aspects of the religiosity of the aljarafe are detailed, very defined natural region and close to the city of Seville. Forms by numerous towns municipalities one of them have their own religious and identity symbols, once it has been marked by the preponderance of unifying symbols the Virgin of Loreto and the Virgen of Rocío. The first, originally linked to the towns of Espartinas and Umbrete, by way of legends of publication, its devotion expands the hand of the observant Franciscans, since the sixteenth century in the convent-sanctuary of Loreto, which has sought to make this image of the region is effective. The Virgen of Rocío from its sanctuary of Almonte has gained from the second half of the last century a powerful influence in the region, luck in most of the towns that have created a brotherhood, I found some of the most ladies of those who come to the village on the feast of Pentecost.

Palabras clave: Símbolos. Rituales. Marianismo. Virgen De Loreto. Virgen Del Rocío. Aljarafe Symbols. Rituals. Marianism. Virgin Of Loreto. Virgen Of Rocío 


\section{Introducción ${ }^{1}$}

La comarca del Aljarafe está formada por treinta municipios de la provincia de Sevilla, surgidos como evolución de las villas y lugares romanas, luego musulmanas que tras la conquista cristiana estuvieron vinculadas a la ciudad de Sevilla por proximidad, vínculos económicos, sociales, jurídicos y religiosos ${ }^{2}$. Las villas aljarafeñas que formaron parte del alfoz de Sevilla pasaron con el tiempo de la jurisdicción real, de las órdenes militares y de la Iglesia sevillana a manos de nobles segundones y de la burguesía de la ciudad, entre ellos muchos caballeros veinticuatros del cabildo sevillano. La comarca era atractiva por su feracidad y cercanía a la capital donde se erigieron numerosas haciendas de olivar ${ }^{3}$. Los traspasos de los derechos señoriales a los concejos de las villas se producirán a lo largo de los siglos XVIII-XIX (Herrera, 1980: 81-85). Durante el Antiguo Régimen y hasta la finalización del régimen señorial, los señoríos seculares del Aljarafe, según el Catastro de Ensenada, fueron: Bollullos de la Mitación y Palomares con Almensilla, que recobran la naturaleza realenga bajo la jurisdicción de Sevilla, reducida entonces a parte de Huévar. El Estado de Olivares, que creara el II conde de Olivares y que engrandeciera el conde-duque don Gaspar de Guzmán, comprendía las villas y lugares de Albaida, Camas, Castilleja, Heliche, Olivares, Salteras, Tomares y San Juan de Aznalfarache. A su muerte, dividió la herencia entre su sobrino Luís Méndez de Haro al que cedió Tomares y San Juan de Aznalfarache, y su hijo legítimo con el marquesado y mayorazgo de Mairena, que incluía: Palomares, Sanlúcar la Mayor, Mairena, Aznalcóllar y Coria. Otras localidades pertenecían al complejo mosaico de jurisdicciones, tanto señoriales como realengas y de órdenes militares, revelador de la complejidad del entramado de poderes del Antiguo Régimen. Umbrete permaneció en manos del Arzobispado y Santiponce en las del monasterio de San Jerónimo (Domínguez Ortiz, 1977).

El Aljarafe perteneció desde la conquista cristiana a la jurisdicción eclesiástica de la Iglesia de Sevilla, a cuyo arcedianato pertenecía; posteriormente se crearán cuatro vicarías: Sevilla, Sanlúcar la Mayor, Aznalcázar y Tejada. Estuvieron fuera de su jurisdicción los estados del conde-duque de Olivares, que creó una entidad vere nullius, exenta del arzobispado con cabecera en la abadía de Olivares, que comprendía las villas y lugares de Olivares, con iglesia colegial, Sanlúcar, la iglesia de la calle Real de Castilleja ${ }^{4}$ y Heliche. Las órdenes militares ejercerán su jurisdicción sobre Villanueva del Ariscal, Villamanrique, Benazuza y Castilleja de la Cuesta (solo la parroquia de Santiago), pertenecientes a la Orden de Santiago; sobre Castilleja de Guzmán, la de Alcántara y sobre Carrión, la de Calatrava, hasta que el señorío pasó al linaje de los Céspedes. Los monjes jerónimos la ejercerán sobre Santiponce, desde la creación del monasterio hasta el siglo XIX (Domínguez Ortiz, 1977). La reorganización eclesiástica preconizada por el Concordato en tiempos de Isabel II supuso el fin de las jurisdicciones exentas y la incorporación de todos los territorios a la jurisdicción del Arzobispado de Sevilla. En 1961-63 el Aljarafe contará con cuatro arciprestazgos: Castilleja de la Cuesta, Pilas, San Juan de A. y Sanlúcar, y 45 parroquias con 77 sacerdotes: 55 diocesanos, 4 residentes y 18 religiosos ${ }^{5}$. Las órdenes franciscana y jerónima regirán las parroquias de Espartinas y Santiponce, respectivamente, y la congregación salesiana las de Sanlúcar y Olivares, dado que contaba con un centro de estudios en las cercanías de la primera población. Actualmente las parroquias de la comarca están incluidas en la Vicaría de la Zona Oeste, que a su vez se subdivide en cinco arciprestazgos: Itálica, Castilleja de la Cuesta, Pilas, San Juan de Aznalfarache y Sanlúcar, en los que en algunos casos se incluyen pueblos que no pertenecen al Aljarafe.

El templo parroquial es con algunas excepciones el único para todos los usos religiosos y residencia de las imágenes, incluso en algunos casos en los que la población se divide a efectos ceremoniales en mitades (Huévar, Mairena del Aljarafe y Salteras), en cuyo interior se acotan espacios, constituyendo verdaderos

\footnotetext{
1 Agradezco a Salvador Hernández González y a Manuel Zurita Chacón, la lectura previa del texto que sin duda se ha enriquecido con sus aportaciones.

2 A los efectos de este texto incluimos en la comarca los siguientes municipios: Albaida del Aljarafe, Almensilla, Aznalcázar, Aznalcóllar, Benacazón, Bollullos de la Mitación, Bormujos, Camas, Carrión de los Céspedes, Castilleja del Campo, Castilleja de la Cuesta, Castilleja de Guzmán, Espartinas, Gelves, Gines, Huévar del Aljarafe, Mairena del Aljarafe, Olivares, Palomares, Pilas, Salteras, San Juan de Aznalfarache, Sanlúcar la Mayor, Santiponce, Tomares, Umbrete, Valencina, Villamanrique de la Condesa y Villanueva del Ariscal (Rodríguez, Villegas y Escalera, 1984).

3 Para un mejor conocimiento de estas peculiares propiedades rústicas y palaciegas puede verse mi libro: Etnografía de la Vivienda. El Aljarafe de Sevilla, Universidad de Sevilla, 1973.

4 La iglesia de Santiago de la plaza de Castilleja pertenecía a la Orden de Santiago (Vicaría de Villanueva del Ariscal y Provisorato de Llerena).

5 Estos datos corresponden a las observaciones de campo y los datos del Informe Etnográfico... de Rodríguez Becerra, Villegas y Escalera. Sevilla, 1984.
} 
"santuarios" dentro del espacio más amplio del templo. Estos son de grandes proporciones con tres naves, de estilo mudéjar y generalmente situados en la plaza mayor o en un punto dominante o cercano a una hacienda (Angulo Íñiguez, 1983). A veces coexisten con una ermita, situándose una de las dos hermandades en el templo parroquial y otra en la ermita, casos de Carrión, Bollullos, Olivares y Castilleja de la Cuesta, o con dos, casos de Aznalcázar y Albaida. En los últimos años han surgido otras tantas ermitas y casas de las hermandades de penitencia y gloria. El panorama de los edificios religiosos de la comarca se completa con los oratorios públicos y privados existentes en las numerosas haciendas de olivar, actualmente sin culto (Rodríguez Becerra, 1973), autorizados por la jerarquía eclesiástica con el objetivo formal de favorecer la asistencia a misa de señores, criados y trabajadores de estas explotaciones agropecuarias. Éstos constituyeron un símbolo de prestigio entre las clases burguesas que podían pagar los servicios de un clérigo que les oficiase las preceptivas ceremonias ${ }^{6}$.

Las devociones supracomunales, es decir, aquellas que incluyen más de un pueblo, son las de la Virgen de Loreto, a cuya romería y novena de septiembre acuden sobre todo Umbrete, Espartinas y Villanueva del Ariscal; la de Nuestra Señora de Cuatrovitas, patrona de Bollullos de la Mitación, a cuya romería del cuarto domingo de octubre concurren al antiguo morabito convertido en ermita gentes de los pueblos limítrofes y de Sevilla; el Cristo de Torrijos, a cuya romería el segundo domingo de octubre peregrinan los de Valencina, con su patrona la Virgen de la Estrella y varios pueblos de la comarca (Escalera, 1990:192-195); a mayor distancia se sitúa por concurrencia y devoción N ${ }^{a}$. S . de la Encarnación de Gerena, a la que se incorporan sin integrarse vecinos de Guillena, que de alguna manera disputan el patronazgo de la imagen; y San Diego de Alcalá en Almensilla ${ }^{7}$. El resto de las poblaciones sólo tienen devociones propias de la localidad, sin que superen sus límites. Caso aparte, por cuanto no es una devoción originada en la comarca, es el de la Virgen del Rocío, devoción que se ha superpuesto e incluso ha hecho disminuir a otras locales y de una antiquísima tradición en alguno de ellos, como es el caso de Villamanrique (Carrasco Díaz, 1970). En conjunto puede decirse que las devociones del Aljarafe son principalmente marianas, pues incluso en el caso de Torrijos, cuya iconografía es un Cristo atado a la columna, Valencina ha incorporado desde 1923 la Virgen de la Estrella que procesiona desde la parroquia a la cercana capilla de la Hacienda de Torrijos (Ortega Santos, 1993).

\section{El marianismo del Aljarafe}

El marianismo del Aljarafe se corresponde con el de gran parte de Andalucía, constituyéndose en uno de los rasgos distintivos de la religión de los andaluces, el dicho "Tierra de María Santísima" no es sólo un tópico, pues puede apreciarse a poco que se conozca esta región (Rodríguez Becerra, 2007). Este carácter religioso se pone así mismo de manifiesto en la investigación antropológica llevada cabo en la comarca en los años ochenta: del total de imágenes de todas las iglesias y capillas de la comarca correspondían un tercio a la Virgen, un quinto a Jesús y el resto a los santos. Si tomamos en consideración la situación de las imágenes dentro de los templos, lo cual es indicativo de la importancia que se le concede a las mismas, y teniendo en cuenta que tienen mayor consideración las situadas en el presbiterio, en segundo lugar, las naves laterales y finalmente en los pies del templo, se confirma que los espacios preferentes están ocupados en dos terceras partes por imágenes de la Virgen (Rodríguez Becerra, Villegas y Escalera, 1984: 486). El retablo de la capilla mayor suele recoger en su parte central la imagen que da la razón fundacional del templo y la titularidad de este, coronado por la Trinidad, debajo un crucifijo y el sagrario a nivel de la mesa de altar; lateralmente otras imágenes secundarias, que en el caso de iglesias conventuales serán santos del panteón sagrado de la orden religiosa ${ }^{8}$.

Y así, de las cincuenta y dos advocaciones generalistas existentes en la comarca, en los lugares preferentes de los templos, se localizan mayoritariamente las advocaciones de la Inmaculada, seguida de cerca por la Virgen de los Dolores, la del Carmen (incluyendo los cuadros de Ánimas) y la del Rosario ${ }^{9}$ y, a mayor

6 La autoridad eclesiástica exigía a los propietarios para autorizar un oratorio público que la capilla fuera digna, estuviera dotada de campana, ornamentos y vasos sagrados, tuviese salida directa al campo y no lindase con dependencias consideradas poco dignas: cuadras, cocinas, etc. (González Moreno, 1998).

7 San Diego de Alcalá (1400-1463), natural de San Nicolás del Puerto, lego franciscano de la Observancia, fue canonizado en 1588 lo que supuso una gran fiesta oficial y popular por ser miembro de esta rama franciscana, sustituyendo a la Conventual por deseo de Felipe II, por ser el único santo del siglo XVI y por haber curado al príncipe Carlos, milagro utilizado en el proceso de canonización. Fue declarado patrón de muchas localidades y se le dedicaron gran número de capillas y conventos. Buena prueba de la notoriedad que alcanzara son las obras dramáticas que escribiera Lope de Vega y las representaciones de Zurbarán, Ribera, Murillo, Gregorio Fernández, Alonso Cano y Pedro de Mena.

8 Las órdenes franciscana y dominica suelen mostrar, en razón de un pacto inicial entre los fundadores, en las calles laterales del retablo en un lado a San Francisco de Asís y en el otro a Santo Domingo de Guzmán.

9 Sobre la presencia de la devoción rosariana en la comarca, véase el elenco de hermandades e imágenes de esta advocación 
distancia, la de Fátima, que suele situarse sobre una peana apoyada en alguno de los pilares de la nave central, la de la Soledad y el estandarte de la Virgen del Rocío ${ }^{10}$. En cuanto a las treinta y cuatro advocaciones específicas, la mayoría también se sitúa en el altar mayor. La explicación de las citadas advocaciones marianas es en parte la misma que para otros lugares de Andalucía: tardía cristianización de la comarca (siglos XIII-XIV) con fuerte presencia de las órdenes religiosas, cercanía a la cabecera de la diócesis y control del clero parroquial, dada la poderosa presencia de la Iglesia sevillana, y la intervención de la corona y los linajes nobiliarios que, como patronos de estas, les correspondía legalmente. Así, el rey Fernando III impuso la devoción a las advocaciones de la Asunción (Cortínez Murube, 1944) o la Merced (Ruiz Barrera, 2005), la casa de Olivares la de las Nieves ${ }^{11}$, y el cabildo eclesiástico sevillano la de la Antigua.

En cuanto a la presencia de Jesús, en expresión iconográfica de Crucificado se da en ochenta y siete casos, muchos de ellos en su primitiva denominación de Vera-Cruz, seguido a gran distancia por Jesús Nazareno, el Sagrado Corazón de Jesús y el Niño Jesús. Hay que hacer notar que Cristo nunca sustituye en la primacía de la devoción a la Virgen, salvo los casos de N.P. Jesús Nazareno de Aznalcázar, Jesús del Gran Poder de Huévar y el Cristo atado a la columna de Torrijos en Valencina de la Concepción. Las imágenes de Cristo tienen especial protagonismo durante la Semana Santa que en el Aljarafe ha gozado históricamente de un cierto esplendor, favorecido por su cercanía a la capital, lo que ha incidido en el seguimiento del modelo sevillano tanto en la conformación del cortejo procesional como en la estética de la imaginería, producida por lo general en los prestigiosos talleres escultóricos hispalenses ${ }^{12}$. Y como sucede en el resto de la región, la conformación de la celebración pasionista hunde sus raíces en la religiosidad contrarreformista, con el impulso al culto de los misterios de la Pasión de Cristo que, si bien estaban muy presentes en la espiritualidad bajomedieval, ahora cobra especial relevancia, a través de la imaginería, como medio de adoctrinamiento de los fieles a través del impacto sensorial destinado a despertar la conciencia de los fieles y moverlos a devoción.

De acuerdo con estas directrices tridentinas, las primeras cofradías de penitencia se rastrean en el Aljarafe a lo largo del siglo XVI, estrechamente vinculadas a la acción apostólica de las órdenes religiosas, especialmente de los franciscanos, quienes darán un fuerte impulso al culto de la Vera-Cruz. No es extraño por ello que las cofradías de la Vera - Cruz sean las más antiguas de la comarca y por ello las de mayor raigambre, hasta el punto de ser las únicas que han perdurado en algunas poblaciones, donde el Crucificado puede procesionar junto a la Virgen de los Dolores (Benacazón, Bormujos, Gines, Villamanrique, Villanueva del Ariscal), de la Piedad (Albaida), de la Soledad (Salteras) u otras advocaciones (Antigua en Olivares, de la Sangre en Huévar). En otros casos, el Crucificado adopta otras titulaciones, como de la Sangre (Huévar) o del Perdón (Puebla del Río).

También de gran poder de atracción devocional son las imágenes de Jesús con la cruz a cuestas, en su tradicional iconografía de Jesús Nazareno, impulsada por la creación de las cofradías del Nazareno a partir de los primeros años del siglo XVII como eco de la sevillana del Silencio, considerada como la matriz de las hermandades de esta advocación. La conmovedora estampa de Cristo cargando la cruz encuentra amplio eco popular en localidades que cuentan con cofradías denominadas tanto de Jesús Nazareno (Sanlúcar la Mayor) como más frecuente del Gran Poder, a imitación de la popular hermandad sevillana. Este es el caso de las hermandades presentes en Bollullos de la Mitación, Castilleja de la Cuesta -popularmente conocida como "la de la calle Real" y una de las protagonistas del destacado ejemplo de hermandades semicomunales que constituye esta población-, Coria del Río, Salteras -donde se repite, aunque bastante más atenuado, este sistema- y Tomares. Otro tipo de hermandad tradicional es la del Santo Entierro (Albaida, Benacazón, Huévar, Pilas, Sanlúcar la Mayor), en las que la imagen del Cristo Yacente que protagoniza esta procesión vinculada a los estamentos oficiales tiene su cotitular mariano generalmente en la imagen de la Soledad (Coria del Río, Huévar, Olivares y Pilas), pudiendo adoptar otras advocaciones como la de los Afligidos en Albaida del Aljarafe. Más escueta representación mantienen hermandades de otras advocaciones cristíferas, como las de la Entrada en Jerusalén (Huévar y Sanlúcar la Mayor), vinculadas a la religiosidad postconciliar del Vaticano II en su idea de sintonizar con la infancia y la juventud; de la Oración del Huerto (Sanlúcar la Mayor); Humildad y Paciencia (Sanlúcar la Mayor); y del Cautivo (Coria del Río y Sanlúcar la Mayor),

recogidos por Romero Mensaque, C. J., El Rosario en Sevilla. Devoción, rosarios públicos y hermandades (siglos XV - XXI). Ayuntamiento de Sevilla, 2004.

10 Este dato no es contradictorio con el actual de que la devoción más notable de todo el Aljarafe es la de la Virgen del Rocío, que se ha institucionalizado en gran manera en los últimos treinta años y se expresa sobre todo a través de los simpecados y rara vez en imágenes.

11 Esta casa tenía especial devoción a esta advocación desde que el Conde de Olivares estuvo de embajador en Roma.

12 Una amplia visión panorámica de la historia y el patrimonio de las hermandades aljarafeñas puede encontrarse en los capítulos específicos de cada una de ellas recogidas en la monumental obra colectiva Nazarenos de Sevilla, Crucificados de Sevilla y Misterios de Sevilla, Sevilla, 1997 - 1999. 
cuya variedad en sus cortejos procesionales y la iconografía de sus titulares quieren romper la tradicional trilogía de hermandades con Nazareno o Gran Poder, Crucificado o Vera Cruz, y Yacente o Santo Entierro.

Mención aparte merece la fiesta del Corpus, otra de las festividades religiosas de gran arraigo en la comarca del Aljarafe. La celebración aparece vinculada a hermandades sacramentales de larga trayectoria histórica, cuya antigüedad se remonta en muchos casos a los siglos XVI y XVII ${ }^{13}$. Esta devoción eucarística, si bien hunde sus raíces en la Baja Edad Media, cobró carta de naturaleza en la comarca durante el Antiguo Régimen, gracias al impulso que le confirieron las directrices emanadas del Concilio de Trento. Este fomento del culto al Sacramento vino por tanto dotado de un sello oficialista emanado del clero parroquial y de las clases altas de la sociedad, si bien la expresión festiva externa enraizó en el nivel popular por la riqueza de los aspectos ornamentales como por el exorno de las calles con colgaduras, arcos triunfales, plantas aromáticas, etc. ${ }^{14}$ La importancia de esta fiesta en el calendario festivo local viene subrayada en algunos casos con la incorporación al cortejo de elementos iconográficos, destinados a completar el mensaje eucarístico, tales como imágenes marianas, especialmente la Inmaculada Concepción por su vinculación con el misterio sacramental, sin olvidar la presencia del Niño Jesús y otras figuras de santos. A pesar de los cambios de fecha impuestos por las reformas litúrgicas y las adaptaciones al calendario civil, todavía se mantiene el jueves siguiente al domingo de la Santísima Trinidad como uno de esos jueves que, según la vieja expresión popular, "relucen más que el sol". Así podemos destacar como ejemplos de esta celebración los Corpus de Carrión de los Céspedes -donde junto a la custodia procesiona la imagen de Nuestra Señora de Consolación, titular de una de las hermandades semicomunales en que se divide la población-, Puebla del Río -donde procesionan las imágenes del Patrón San Sebastián y la Patrona Nuestra Señora de la Granada-, Salteras -donde se celebra el 15 de agosto, festividad de la Asunción, momento en que acompaña al Santísimo Sacramento la imagen de la Patrona, Nuestra Señora de la Oliva- y Villanueva del Ariscal -que por herencia de su histórica vinculación con la Orden de Santiago, lo celebra el 25 de julio con un colorista cortejo procesional en que figuran varios pasos con la custodia procesional, Santiago Apóstol ecuestre, la Inmaculada, el Niño Jesús, San Francisco de Asís, etc.-

La escasa presencia y devoción a los santos es una nota característica actual de la religión de los andaluces, salvo la de algunos de reciente creación debido a su fama de milagrosos ${ }^{15}$; son escasos los santos y mártires medievales y modernos, generalmente taumatúrgicos ${ }^{16}$, como consecuencia de la tardía cristianización de Andalucía, a diferencia de otras regiones y comunidades españolas. Los existentes son santos generalistas ligados a las órdenes religiosas, así San José, impulsado por la Contrarreforma, por los carmelitas descalzos y por todo el clero, estaba relacionado con la buena muerte; San Antonio de Padua, conocido por su capacidad para terminar con la soltería femenina y San Francisco de Asís, ambos estrechamente vinculados a la poderosa orden franciscana ${ }^{17}$; le siguen San Juan Bautista, en ocasiones como san Juanito, ligado a la capilla bautismal, San Juan Evangelista, San Sebastián, el santo protector contra las pestes junto con San Roque, y Santa Ana que con la Virgen Niña y San Joaquín constituían el modelo de familia cristiana. Es significativo que los dos santos de más amplia presencia en su iconografía: San José y San Joaquín, figuran con el Niño Jesús, por lo que parece razonable pensar que fueran considerados especiales protectores de la infancia en una época en que la mortalidad infantil alcanzaba altas cotas.

La pérdida devocional a los santos, incluidos los taumatúrgicos, ha coincidido con el incremento de la devoción a la Virgen; ello puede observarse por el escaso culto externo que reciben, incluso se ha suprimido, salvo excepciones, como en los casos de San Roque en Villamanrique, San Diego de Alcalá en Almensilla, San Miguel en Castilleja del Campo, San Juan Bautista en San Juan de Aznalfarache o San Bartolomé en Umbrete. Los santos patronos de las villas como san Sebastián que lo es de nueve localidades, pero también San Roque, San Ginés, San Benito o San Isidoro, no reciben culto ni devoción o están muy disminuidos y sólo les queda alguna función de iglesia. Los retablos de Ánimas, también conocidos como "Ánimas del Purgatorio" o "Ánimas benditas" están presentes en todas las parroquias como consecuencia de lo preceptuado e impulsado por el Concilio de Trento, con frecuencia utilizando a la Virgen del Carmen

\footnotetext{
13 Una buena síntesis del desarrollo histórico de esta celebración en la comarca se recoge en Amores Martínez, 2003.

14 Esta fiesta alcanzaba y alcanza en Andalucía las cotas más altas de esplendor en las sedes arzobispales de Sevilla y Granada, en donde al abundante clero secular y regular se unían los gremios y otras instituciones junto a la popular tarasca, los gigantes y cabezudos, las rocas o carrozas que formaron parte del cortejo hasta las prohibiciones de Carlos III.

15 En este sentido son especialmente venerados San Pancracio, San Martín de Porres y el lego capuchino no canonizado fray Leopoldo de Alpandeire.

16 Los mártires de época romana y musulmana reales o ficticios fueron declarados patronos en las localidades en las que se suponía nacidos, según los falsos cronicones. El caso de san Eustaquio patrono de Sanlúcar puede ser una excepción., junto a San Sebastián y San Roque.

17 En la comarca existieron conventos franciscanos en Castilleja de la Cuesta (de corta existencia), San Juan de Aznalfarache, Espartinas (Loreto) y Villamanrique, pero la influencia de las órdenes mendicantes no se explica solo por la presencia en conventos, sino también por el área de influencia creada por las misiones populares, las predicaciones, la petición de limosnas, etc.
} 
como intercesora, pero también a la Trinidad y otros seres sagrados. Ello supuso una respuesta a la posición protestante que negaba el valor a las buenas obras como fuente de purificación del alma de los vivos y los muertos. Por otra parte, el culto a las Ánimas y los enterramientos se convirtieron en una fuente de ingresos muy saneada, tanto para el clero secular como regular. El relativo descenso del culto a los difuntos, que ya era notorio en las últimas décadas del siglo pasado, se ha incrementado en gran manera, habiendo desaparecido o disminuido los lutos, los excesos en el ornato de las tumbas y las velas y responsos en los días de Todos los Santos y Difuntos.

Los más frecuentes patronazgos en los pueblos del Aljarafe se caracterizan por su dualidad, de forma que tienen un patrón masculino, generalmente un santo y una patrona, que siempre es alguna advocación de la Virgen, esto ocurre en veintitrés de los treinta pueblos de la comarca. En la práctica, el patrocinio efectivo corresponde a alguna de las advocaciones de la Virgen, en tanto que el de los santos está prácticamente olvidado $^{18}$. En la mayoría de los casos estos patronos no son canónicos, es decir, no existe documento de la Iglesia jerárquica que lo establezca, aunque sí acuerdos municipales y votos perpetuos, pero el tiempo los ha convertido en patronos como consecuencia de los supuestos favores recibidos o sentidos; en no pocos casos estos seres patrocinadores se confunden con los titulares de las iglesias parroquiales.

Existen por otra parte una serie de imágenes que, no siendo patronos canónicos, funcionan como tales; es el caso de Nuestro Padre Jesús en Aznalcázar, Nuestra Señora de Belén en Pilas, la Virgen del Rocío en Villamanrique y la de los Dolores en Camas, a los que se les tiene más devoción que a los propios patronos. En otros tantos pueblos dos advocaciones de la Virgen funcionan simultáneamente como tales para cada una de las secciones en el que pueblo se agrupa para darles culto, tal es el caso de Carrión de los Céspedes y Castilleja de la Cuesta (Aguilar Criado, 1983; García Benítez, 2002). En algunos de éstos existe una tercera imagen, cristífera que, superando la profunda y apasionada división en torno a dos símbolos marianos, unifica a la comunidad; tal es el caso de N. P. Jesús de Aznalcázar y Jesús del Gran Poder en Castilleja de la Cuesta. El patronazgo de la Virgen es mayoritario en los pueblos de la comarca y sigue creciendo, pues en veinte casos es la patrona oficial y efectiva y en otros cinco funciona de hecho como tal. En nueve pueblos las imágenes patronales han sido sustituidas por otras tantas advocaciones marianas, y en un solo caso, Cristo funciona como patrón efectivo.

La religiosidad también se expresa en los azulejos que los vecinos colocan en las fachadas de sus casas, muchas de ellas construidas en los últimos años, la mayoría son de la Virgen del Rocío, seguida a cierta distancia del Gran Poder, la Inmaculada, el Carmen y los Dolores; también existen azulejos en las fachadas de iglesias, capillas, ermitas, fuentes y hasta en las casas consistoriales. No faltan tampoco en las haciendas, pero las representaciones cerámicas de éstas son de iconografías más variadas, pues obedecen a las devociones y gustos de sus propietarios y son de mayor antigüedad. Los más antiguos representan a la Trinidad, San Antonio de Padua, la Virgen del Carmen y las Ánimas ${ }^{19}$.

Concluimos reafirmando que la comarca del Aljarafe en su conjunto no tiene un patrón o patrona efectivo, a pesar de que algunas imágenes de María como la Virgen de Loreto ostente oficialmente el título de Patrona del Aljarafe sevillano desde 1959, o que la Virgen de Cuatrovitas, patrona canónica de Bollullos desde 1957 haya sido declarada patrona del Verdeo, por el predominio de la aceituna de mesa en la comar$\mathrm{ca}^{20}$ a pesar de que su patrocinio se extiende a poco más de cuatro o cinco pueblos. La advocación de María que puede ostentar el título de Patrona de hecho por la devoción que concita, expresada en la presencia en su romería de Pentecostés y en la existencia de hermandades rocieras, es la Virgen del Rocío. Todos los pueblos del Aljarafe salvo tres tienen hermandad del Rocío, por lo cual en sus templos parroquiales existe un altar donde recibe culto la imagen a través de su Simpecado. Sin temor a exagerar, puede decirse que el Aljarafe es una de las comarcas con más fervor rociero a pesar de que su presencia en el conjunto de la comarca es reciente, y que la Virgen del Rocío es considerada como su patrona. En la comarca tienen lugar algunos de los actos más emblemáticos de toda la romería, como el paso de las hermandades por la población de Villamanrique y el paso del río Guadiamar por el Vado de Quema en Aznalcázar, ambos actos declarados Fiestas de Interés Turístico Nacional de Andalucía en 1999 y 2002, respectivamente.

\section{La Virgen de Loreto y su santuario}

La Virgen de Loreto está unida íntimamente a su santuario y convento de franciscanos, "a cuya solici-

18 Queda un testimonio en los nombres que se imponen a los naturales de una comunidad; tal es el caso de San Eustaquio en Sanlúcar. Esta tradición ha sido radicalmente sustituida por nombres más televisivos o cinematográficos y desde luego, más exóticos.

19 Un ensayo de catalogación de estas muestras de cerámica devocional puede verse en Pleguezuelo Hernández, A., “Azulejos hagiográficos sevillanos en el siglo XVIII”, en Archivo Hispalense, 191 (1979), pp. 167-190.

20 La Virgen de la Oliva, patrona de Salteras fue declarada patrona de los olivareros de Sevilla por el Sindicato Provincial del Olivo en 1953, sin que conste que su devoción fuera más allá de la citada población ni el referente canónico. 
tud, guarda y piedad, se debieron, en todos tiempos, los mayores esplendores del culto, el incremento de devoción, conservación del mismo santuario, y las noticias históricas providencialmente conservadas en su Archivo hasta nuestros días". El libro del P. Ortega, del que tomamos estas palabras se propone llenar un hueco, "pues mientras otras imágenes, acaso de menos renombre, tienen su historia escrita, de ésta muy poco han hablado. No la cita Villafañe, ni don Vicente de la Fuente ni otro historiador de los santuarios más celebres de María en España la mientan", autores ambos de sendas historias de los santuarios marianos españoles (Ortega, 1907: 8). El fraile autor de este opúsculo, aunque justifica la necesidad de la publicación, está indicando a su vez que el santuario no era conocido más allá de sus cortos límites como demostraremos más adelante.

El Santuario se encuentra en medio de olivares y viñedos y no es santuario de un pueblo concreto; hasta hace poco pasaba la carretera nacional de Sevilla a Huelva por sus inmediaciones, en cuya entrada existe un monolito que marca el acceso al santuario. Anexa y sin solución de continuidad en la construcción, se encuentra la hacienda y su característico mirador. El convento y santuario están rodeados de cipreses, con alta espadaña y una torre mocha o atalaya de cronología medieval. El convento, por ser de franciscanos observantes, muestra su pobreza y espíritu monástico. La iglesia, lo mejor del conjunto, muestra la austeridad de líneas de la arquitectura franciscana, matizada sólo por la riqueza ornamental de los retablos que ocupan el presbiterio y los diferentes tramos de la nave. Construida entre 1716 y 1732 para sustituir el templo primitivo, sólo conserva de la anterior la capilla mayor, convertida en sacristía en la actualidad. El retablo principal es una gran pieza del barroco dieciochesco, el camarín es sencillo y tiene acceso por amplias escaleras, como cuadra a un santuario de gran afluencia en determinadas ocasiones. La imagen es muy pequeña $\mathrm{y}$ ha sufrido diversas restauraciones que han transformado su impronta primitiva ${ }^{21}$.

La fundación del convento del Loreto en las primeras décadas del siglo XVI se produjo, como era frecuente en aquellos tiempos y anteriores, sobre una ermita preexistente. Las primeras noticias de la ermita son de 1384, según el manuscrito que comenzó a escribir el P. Francisco de Angulo, morador de dicho convento (1584), hasta cuya época relata. El manuscrito se conserva en Loreto y ha servido de guía a la historia de fray Ángel Ortega ${ }^{22}$. El lugar de Loreto, conocido al menos desde época musulmana, fue sede de una ermita con la advocación de $\mathrm{N}^{\mathrm{a}}$. $\mathrm{S}^{\mathrm{a}}$. de Valverde por el nombre del paraje. En 1525 tomó su actual nombre de la finca Loreto donde se asentaba. La analogía con la imagen de la ciudad italiana del mismo nombre es nominativa y muy posterior. Vemos pues que el icono mariano cambia de nombre en función del topónimo, prueba de la estrecha relación entre el lugar donde se da culto a una imagen y su nombre, lo que abona la teoría de las hierofanías de Mircea Eliade, por la cual en algunos lugares se muestra lo sagrado que resulta ser más permanente que los iconos que los albergan.

Esta presencia de lo sagrado-mariano se expresa a través de leyendas de aparición o hallazgo que explican la presencia del ser sagrado, que no es obra de seres humanos, cualidad que se hace pública mediante algún milagro, por el propio hecho de la aparición que se explicita como extraordinario o por algún favor recibido por personas aparentemente no conectadas con la imagen concreta. Dos leyendas avalan la presencia de la imagen de Loreto en el lugar, una que sitúa los hechos en 1384, debida a fray Francisco de Angulo, morador del convento, cuyo manuscrito se conserva en el cenobio y según vimos empezará a escribir en 1584 "tal cual la había recibido por tradición"23 y otra adjudicada a fray Felipe de Santiago y otros frailes del convento de la Rábida, que sitúa el suceso hacia 1484, que se escribiera a lo largo del s. XVII ${ }^{24}$. El texto de fray Francisco de Angulo describe así el milagroso suceso:

"En Berbería estaban unas cristianas captivas cociendo unas madejas de su ama, día señalado de Sábado Santo. Platicando estas de su trabajo, se les vino a la memoria que el día siguiente era de Resurrección del Señor: en el cual los cristianos hacían gran fiesta y se regocijaban mucho. De esto se les dobló a ellas la aflicción y llorando muy amargamente enderezaron los ojos de su ánima, y

\footnotetext{
21 Los orígenes de este cenobio franciscano y su historia posterior resultan en general bien conocidos, gracias a antiguas crónicas franciscanas, tanto manuscritas como impresas, condensadas modernamente en la monografía elaborada por el P. Ángel Ortega a comienzos del siglo XX (Ortega, 1907) y, más recientemente, las aportaciones de F. Amores Martínez desde el punto de vista histórico - artístico (Amores Martínez, 2007: 115 - 132).

22 Existe otro manuscrito semejante en el convento de San Buenaventura de Sevilla: Fundación del Convento de Ntra. Sra. de Loreto y Historia de los milagros que en ella se sucedieron y noticia de algunos siervos de Dios que en el han vivido, por fr. José González (1681).

23 Libro memorial de la fundación y cosas notables deste Convento de nuestra Señora de Loreto y novicios que se han recibido y de las visitas que en el se han hecho; lo comenzó a escribir Fray Francisco Angulo, predicador y morador del convento de Loreto en 1584.

24 Libro en que se trata de la antigüedad del convento de $N^{a}$. $S^{a}$. de la Rávida y de las maravilla y prodigios de la Virgen de los Milagros (1714), comenzado a escribir por el lego fray Felipe de Santiago y continuado por otros frailes del convento de la Rábida, cap. XXII (Santiago, 1990).
} 
los suspiros de su corazón a la sacratísima Virgen María nuestra Señora, rogándole que como su Hijo las había consolado en aquel día de tristeza y lágrimas de su Pasión, así ella tuviese por bien de alegrarlas y libertarlas de aquella miseria y cautiverio en que a la sazón estaban”.

Con esta oración y lágrimas se sentaron aquellas pobres mujeres cerca de la caldera: y siendo natural de la tristeza acarrear sueño se quedaron allí luego dormidas. Más porque ellas habían puesto su confianza en Dios, y en su benditísima Madre, que también lo es de misericordia: tuvo por bien de socorrerlas, y darles la libertad y gracia que le demandaban. Estando pues así caídas en aquel sueño, vino a ellas la Reina de los Ángeles y sin que despertasen ni sintiesen alguna cosa las puso en un instante en esta laguna y prado que está frente del compás del Convento. Trajo también con ellas como por testigos el fuego, trébedes y caldera, donde se cocían las madejas. Y por autorizar más el milagro, y que se entendiese cierto ser obra de su liberalísima mano, dejó allí con ellas esta sobredicha imagen suya, que después ha sido consuelo y socorro de todos estos pueblos comarcanos. De esta manera amanecieron aquellas buenas mujeres el domingo de la Resurrección en este lugar; donde hallándose entre cristianos, y vistas de ellos no sin mucho sentimiento, y devotas lágrimas de confesión y alabanza; dieron todos infinitas gracias a Dios que tan misericordiosamente las había sacado.

Enterados del prodigio los habitantes de Umbrete acudieron al lugar del suceso, en devota procesión, llevándose la Imagen a su Iglesia y hospedando a las afortunadas cautivas en sus casas. Pero no eran estos los designios de la Virgen Santísima y una y otra vez se volvió la Imagen al mismo sitio; por lo cual comprendieron que, allí en aquel sitio, quería ser venerada y trataron de edificarle una ermita" (Romero Meilán y otros, 2000: 5-6. Texto actualizado en su ortografía).

Por su parte, el texto de fray Felipe de Santiago relata la aparición de la imagen mariana en un contexto distinto, tanto de sus protagonistas como de su cronología:

"Por los años del Señor de mil cuatrocientos ochenta y cuatro, yendo Amaro Fernández, vecino de Espartinas, a Sanlúcar con su buena mujer María Amata, y sus hijos, que era un año de gran carestía y seco /92v/. Iban en santa conversación y con mucha necesidad y se pusieron a rezar a la Madre de Dios [para que] los socorriese. Y junto a un tronco de un olivo vieron puesto una toalla que parecía a modo de mesa, y llegando hallaron unos panes muy recientes con que socorrieron su necesidad. Y daban las gracias a María Santísima y estando en estas alabanzas repararon que del olivo salía gran fragancia y registraron qué era la causa, y hallaron a la Virgen Santa María Madre de Dios. Y comenzaron con tanta devoción y alegría y muchas lágrimas postrados a sus pies pidiendo misericordia, y remedio para tantas necesidades. Y acudió un sacerdote que en la torre del Loreto estaba haciendo vida santa, y le contaron lo sucedido, y el remedio que había hecho para su enfermedad la Virgen Santísima. El buen sacerdote la tomó con mucha devoción y la llevó a la torre de su retiro, y dejando a la familia en compañía de la Señora se fue a Espartinas, y dio la noticia de todo lo referido y se conmovió todo el pueblo. Y él ordenándolo vinieron en penitencia, y en rogativa para que esta Señora fuese a su remedio. Y cuando llegaron hallaron la tierra florida desde el olivo hasta la torre que era una maravilla, y estando la tierra tan seca pues era día dos de febrero y todavía no había llovido, todos admirados. Y de aquí llamaron a esta Señora de Villaviciosa o de Valle Verde, que el nombre de villa lo tenía aquel sitio. Y también se halló un escrito que decía así: "Berardo, y sus compañeros me pusieron aquí, minoritas [frailes menores franciscanos] que entraron a predicar en Sevilla a los moros, para ver si admitían la fe y no habiéndola admitido les hicieron malos grandes tratamientos, y no pudieron volver /93/ por mí. Y de Italia me traían por su compañía y guía. Y soy de Santa María de Huertas de Nápoles. Y el buen sacerdote guardó estos escritos como reliquias teniendo que los menores eran los santos Mártires de Marruecos de San Francisco ${ }^{25}$. Y también le llamaron a esta Señora de Loreto por ser dicha torre de iglesia hasta que labraron otra. Y también fueron socorridas las necesidades, y llovió, de que todo aquel país tomó mucha devoción con esta Señora, y también la ciudad de Sevilla. Y son muy continuos sus milagros en todo género de enfermedades, y en tormentas de mar y tierra" (Santiago, Fray Felipe de: 197-198. Texto con ortografía actualizada).

Como en tantas otras ocasiones, si no en todas, son los frailes los que dicen recoger de la tradición estas narraciones de aparición o hallazgo de la Virgen y, aunque así fuera, le daban forma al ponerlas por escrito, procurando no contradecir la postura oficial eclesiástica, pues de esta manera no suscitaban sospecha del

25 Berardo y cuatro compañeros, protomártires franciscanos, fueron enviados por San Francisco a predicar a los musulmanes en el siglo XIII, pasaron por Sevilla y finalmente a Marruecos donde fueron martirizados. Posteriormente fueron canonizados. 
tribunal de la Inquisición, fijando definitivamente el texto. Los textos legendarios obedecían a unos prototipos culturalmente aceptados y aplicados a cada advocación mariana concreta -que así se singularizaban e identificaban con una población- y que los predicadores repetirían cada año en los sermones en las respectivas fiestas locales. Resulta lógico pensar que los frailes no fueran ajenos a la creación y difusión de estas tradiciones, las que procuraban contextualizar y dotar de pasajes concretos que las hicieran más cercanas, dentro de los varios modelos culturalmente ya creados y acertados; así por ejemplo el cautiverio en el norte de África era algo muy cercano a los andaluces de los siglos XVI y XVII y buena prueba de ello eran las cadenas y grilletes que colgaban de no pocos santuarios, ofrecidos por cautivos liberados por intercesión sobrenatural.

Entre las versiones de las leyendas de aparición de fray Francisco y fray Felipe, ambos de la Recolección franciscana, hay marcadas diferencias: a) las fechas en que sitúan los hechos; llama la atención que el primero las sitúa en 1384 y el segundo en 1484 y que a su vez fray Francisco empezara a escribir en 1584, lo que pudiera deberse al baile de números que se produjera en la transmisión oral o a un error en la trascripción del texto más antiguo; b) en cuanto a las fechas en que escribieron los frailes, la primera versión es anterior en casi ciento cincuenta años de la escrita en la Rábida, en la que sus varios autores debieron hacerlo en el primer tercio del siglo XVIII ${ }^{26}$; c) la versión del primero es más escueta y otorga el protagonismo a unas mujeres innominadas, cautivas en Berbería, pero sobre todo al pueblo de Umbrete, alojando a las cautivas liberadas milagrosamente y apropiándose del simulacro, y que sólo aceptarán que no se quede entre ellos, cuando la imagen expresa su soberana voluntad trasladándose al lugar de la aparición. La plena posesión de la imagen por los umbreteños la deja en el aire el fraile de Loreto diciendo que "trataron" de hacerle una ermita.

La segunda versión, mucho más elaborada, obedece a otro modelo más común, la aparición de la Virgen sobre un árbol, aunque luego establece concomitancias con el tipo de la virgen de la Hiniesta, que a través de un texto fija su origen, establece sin documentarlo la fecha exacta del hecho, los nombres de los videntes y otras circunstancias como el día exacto, y reparte el protagonismo entre la familia que la encontró, el fraile que rezaba en la torre [mocha] y el pueblo de Espartinas que acude al llamamiento del religioso. Luego mediante el ardid del texto aparecido que explica su origen, conecta el hallazgo con Santa María de Huertas de Nápoles (aunque pudiera ser un error y se refiera al monasterio cisterciense de dicha advocación emplazado en tierras de Soria), y sobre todo con los primeros mártires franciscanos y la ciudad de Sevilla; d) El testimonio de veracidad del suceso trata de demostrarse en el primer caso con la presencia del fuego en el lugar de aparición, las trébedes y la caldera -que fueron pintadas en una pared de la iglesia- y en la propia presencia de la imagen o simulacro que la Virgen les dejó, evitando de esta forma el peligro de herejía que la presencia corporal de la Virgen habría desatado; en el segundo con datos concretos de nombres y fechas, testimonios históricos verdaderos o falsos y criterios de autoridad como la referencia a los mártires.

Estas leyendas que justifican la presencia de la Virgen en un determinado lugar, es una tradición transmitida de padres a hijos. Casi todos los santuarios de María tienen leyendas piadosas y orígenes milagrosos, nos dice Ortega, que solo se hace eco de la primera versión ¿por qué no admitirlas?, ¿tendrá, acaso más valor, el frío análisis de una crítica racionalista que el sentimiento general del pueblo cristiano...? El milagro estuvo pintado ante la puerta de la Iglesia. ¿Quién fabricó la imagen? La imagen, según la leyenda tradicional, fue trasladada milagrosamente con las mujeres, el fuego, las trébedes y la caldera a este sitio. Esto es suficiente para hacerla digna de veneración (Ortega, 1907: 16). Los habitantes de Umbrete acudieron y se llevaron la imagen a su iglesia y a las mujeres las alojaron. La Virgen se volvió una y otra vez al mismo sitio. La otra versión identifica nombres y naturaleza de los videntes. La doble leyenda no hace sino recoger el enfrentamiento por la posesión real o simbólica de este lugar sagrado que puede tener un trasfondo material, de los vecinos de ambas poblaciones.

Se hizo la ermita y empezó a ser venerada la imagen con el título de Valverde hasta 1520, por analogía con el topónimo del lugar, aunque debió existir con anterioridad. Esta práctica era muy común: el que las imágenes de la Virgen fueran conocidas por el lugar geográfico en donde se situaban sus ermitas, que frecuentemente se referían a denominaciones geográficas que vinculaba sin ambigüedades una determinada advocación a un lugar y a una población, a diferencia de las advocaciones más oficiales y generalistas que se referían a misterios marianos, que habían sido declarados fiestas por la Iglesia o habían sido introducidas por alguna orden religiosa. Recuérdese que el nombre original de la Virgen del Rocío fue el de La Rocina, y posteriormente pasó a denominarse del Rocío, advocación de connotaciones más universalistas y a vincularse con Pentecostés por la fecha de su fiesta. En la primera época acudían de los pueblos a diario, dice Ortega, se hacía la "fiesta con grandes demostraciones de culto y festejos populares: se repetían los prodigios que venían a aumentar el entusiasmo y gratitud de todos. La Virgen de Valverde era la Madre y Reina de todo el Aljarafe", expresión más de un deseo del fraile que de una realidad (Ortega, 1907: 17). El 
convento trata de esta forma de superar el localismo que no beneficiaba sus aspiraciones evangelizadoras y sus intereses económicos y convertir a la imagen de Loreto en una devoción comarcal.

La realidad de los hechos es que, sobre una ermita preexistente dedicada a la Virgen de Valverde, también conocida como de Loreto, la omnipresente orden franciscana se establece en aquel lugar con la autorización de don Alonso de Manrique, cardenal-arzobispo de Sevilla. Un hecho particular hizo que se fundara el cenobio y se llamara de Nuestra Señora de Loreto. La ermita en cuestión estaba cerca o junto a la hacienda denominada de Loreto, propiedad de don Enrique de Guzmán y doña María Manuel, "ambos ilustres sevillanos", como dice Ortiz de Zúñiga en sus Anales correspondientes al año 1525. Esta señora, viniendo hacia sus posesiones del Aljarafe, sufrió un accidente en el puente de Triana, en el que, aunque no recibió daño, quedó en una actitud poco honesta. Interpretando esta herida a su orgullo como una llamada de Dios para dejar la vida frívola, se retiró a su hacienda de Loreto, donde aconsejada por religiosos de la orden y dado que carecían de descendencia, decidieron fundar un convento de franciscanos garantizándose como tantos linajes nobiliarios, un lugar preferente para sus restos y los de sus descendientes en la capilla conventual y culto permanente para sus almas.

Una vez recibida la licencia del arzobispo el 13 de junio de 1525, los fundadores dieron posesión de la ermita y terrenos para la nueva fundación a los franciscanos, en la persona de fray Juan de Medina, Provincial de Andalucía, como así lo refieren las crónicas:

"Y en señal de posesión entró en dicha iglesia de Nuestra Señora Santa María de Valverde: e anduvo por ella, se subió en el altar mayor e tomó unos candeleros y los quitó de una parte y pasó a otras y se paseó por la dicha iglesia e tomó las llaves de ella y cerro sobre sí la puerta echando de ella a ciertas personas que ende estaban e abrió la dicha puerta y la tornó a cerrar. Todo lo cual dijo que hacía en señal de verdadera y pacifica posesión, que de la dicha iglesia para hacer el dicho monasterio tomaba y aprehendía, y tomó y aprehendió y lo pidió por testimonio".

Actos llenos de significado y clara forma de hacer patente la propiedad efectiva y jurídica sobre un inmueble; estuvieron presentes en el acto de toma de posesión el alcaide y alcalde mayor de la cercana villa arzobispal de Umbrete, el alguacil mayor del arzobispado, el alcaide de las casas arzobispales y, por supuesto, el notario apostólico. Estos datos nos ponen de manifiesto el interés del arzobispo por esta fundación situada a dos pasos de su señorío y palacio de Umbrete y reflejan un ritual civil lleno de contenido simbólico comprensible para todos, pues el provincial realiza acciones que se consideraban específicas de un propietario. Todo ello, con testigos y ante notario. Dicho acto fue recurrido por un caballero que hizo valer su derecho como patrono sobre una capilla de la ermita preexistente, por lo que planteó pleito para tratar de impedir el establecimiento de los frailes. Sin embargo, el pleito no sólo no prosperó, sino que la familia demandante, según recoge el historiador conventual con duras palabras, fue castigada por Dios, arruinando su familia y casa. Vencidas estas dificultades, se inició la fábrica del convento, que según el padre Gonzaga quedó concluido en 1528 gracias tanto al patrocinio de los fundadores como al concurso de los pueblos comarcanos, siendo su primer guardián fray Juan de Granada.

El llamarse la torre de Loreto y alguna analogía que encontraron con el milagro y traslado de la casa de la Virgen de Palestina a Italia, "fueron el motivo de mudar el título de Valverde por el de Loreto, que aplicaron igual e indistintamente a la Virgen y al Convento" (Ortega, 1907: 24). La devoción antigua se hizo general y entusiasta y se aumentó la concurrencia. La vida observante y el apostolado en los pueblos eran como un poderoso imán, dice Ortega. Loreto se hizo universalmente popular e intensamente querido de todos. Doña María Manuel vendió su hacienda al conde de Castellar, cedió su derecho de patronato a su hermano Pedro Ortiz Manuel, se fue a vivir al compás del convento de Santa Clara de Sevilla y luego profesó en el recién fundado de Santa María de Jesús, de la misma orden de Santa Clara. Murió en 1543 con fama de santidad y su cuerpo estuvo incorrupto durante años.

El convento de Loreto fue el primero de la familia recoleta en Andalucía ${ }^{27}$. El lugar era especialmente idóneo para llevar a la práctica los ideales de los franciscanos recoletos: la mayor perfección, la castidad, la pobreza y la estrechez del convento, a diferencia de los soberbios cenobios que se levantaban en las ciudades, lo que les decidió a crear aquí el noviciado de la provincia. Este convento franciscano, como otros

27 El franciscanismo a lo largo de la historia ha tenido varias ramas: Observantes, para distinguirlos de los Conventuales que "admitieron rentas y una mayor amplitud de vida" y Capuchinos. Los Recoletos son complementarios de los Observantes, que les estuvieron siempre sujetos. Hubo conventos de la recolección en cada provincia observante para aquéllos que querían una mayor perfección. Los Capuchinos constituyen una rama independiente. En el capítulo de Baeza de 1583, siendo Provincial Francisco de Gonzaga, se dividió la provincia de Andalucía en dos: Andalucía con 31 conventos de frailes y 15 de monjas y Granada con 26 conventos masculinos y 20 femeninos. 
de la Bética, y de otras tantas órdenes mendicantes, fueron base de preparación para el salto a América y Filipinas de numerosos frailes y algunos obispos para la colonización-evangelización del Nuevo Mundo. La Iglesia fue restaurada y ampliada con capilla mayor en 1607 por el guardián fray Baltasar de Cepeda; los gastos debieron ser cuantiosos "pero ningún oro vino de América"; ayudó el arzobispo Don Fernando Niño de Guevara, devotísimo de la Virgen de Loreto, que la consagró. A la ceremonia acudieron las dignidades y música de la catedral y "concurrieron la mayor parte de la gente de estos pueblos y de Sevilla a esta fiesta" (Ortega, 1907: 34).

La comunidad de Loreto estaba incapacitada por su regla de Observantes para disfrutar de mandas perpetuas y obligatorias por tratado jurídico. Ello provocó algunas limitaciones, pero, como otros tantos conventos, tuvo sus patronos que se obligaban a ciertas ayudas permanentes a cambio de ciertos servicios religiosos y derecho a enterrarse en el templo. El dilema lo resolvieron los frailes mediante un acuerdo amistoso; por otra parte, los patronos no se enterraron siempre ni tampoco cumplieron con lo estipulado. En el patronato del convento se sucedieron varios titulares por herencia ${ }^{28}$ que al parecer estaba vinculado a la casa y mayorazgo de Loreto, pero a comienzos del XVII, recayó en manos del linaje del conde-duque de Olivares. En efecto, el Provincial de Andalucía se dirige en 1610 a don Gaspar de Guzmán, concediéndole el patronato del convento de Loreto, aunque "no [era] del todo conforme al espíritu de la Recolección", a cambio de "limosnas y socorros temporales" para reedificar y reparar el convento e iglesia y que en su capilla mayor puedan enterrarse ellos y los religiosos del convento, así como poner las armas e insignias de su nobleza y casa, y además:

"en su vida y en muerte gocen Vuesas Mercedes generalmente de todos los sacrificios de las misas que en el dicho convento se dijeren, y de las oraciones y sacrificios, oficios divinos, ayunos, estaciones, vigilias, predicaciones, confesiones, disciplinas, penitencias, lecciones, peregrinaciones, meditaciones y de todas las demás obras pías y virtuosas a Dios aceptas, que la Divina Majestad por su gran misericordia ayude a hacer a los religiosos del dicho convento de Ntra. Sra. de Loreto" (Ortega, 1907:38).

Desde entonces los patronos y sus descendientes tendrían bóveda para su entierro en la capilla mayor, por cuyas almas los frailes quedaban obligados a decir cuatro misas rezadas diarias y otras tantas cantadas en las principales solemnidades. A cambio los patronos entregarían anualmente al convento 150 fanegas de trigo procedentes de las villas de Olivares y Heliche, completadas con 60 fanegas de cebada y 400 ducados en metálico, sin olvidar las limosnas eventuales con las que se acudía al mantenimiento y reparación del edificio conventual. La herencia del Conde-Duque pasó a su sobrino Luis de Haro y a comienzos del pasado siglo llegó a manos del duque de Berwick y Alba. A lo largo del siglo XVII se recibieron una serie de mandas o legados testamentarios otorgados por devotos en Sevilla (4), Espartinas (5), Sanlúcar la Mayor (3), Villanueva del Ariscal (2), Castilleja de la Cuesta (1) y Salteras (1), que incluían dinero, trigo y aceite, sayal para los frailes, pescado y pan amasado para el Viernes Santo, bulas para religiosos, capellanías, dotes para doncellas y huérfanas, etc. Una nueva etapa comenzó a partir de mediados del siglo XVII con la vinculación establecida con los condes de Castellar y marqueses de Moscoso, que arranca de la donación hecha en 1649 por Fernando de Saavedra, caballero de Alcántara, de 1.000 ducados de renta anual, extraídos de su heredamiento de Tablantes y destinados a la manutención de los profesores y estudiantes de la casa. En 1681 se implantan los estudios de Filosofía y Teología, por lo que la comunidad fue muy numerosa desde esa fecha.

Esta línea ascendente de la casa franciscana de Loreto tuvo su reflejo material en el aspecto artístico, especialmente en la profunda remodelación acometida a lo largo del primer tercio del siglo XVIII. De este programa de reformas destaca la construcción de la nueva iglesia, consagrada en 1733. Esta obra contó con la ayuda del ilustre fray Francisco Buenaventura, dos veces guardián del convento, que elevado a la dignidad episcopal ejerció como obispo en varias diócesis americanas y llegó a arzobispo de Guadalajara. Esta acumulación de fábricas de distintas épocas y estilos es responsable del valor artístico de esta casa franciscana. Así el cenobio cuenta con dos claustros, uno del siglo XVI y el segundo del XVIII, y un gran patio de finales del XX que sirve de transición con la vecina hacienda a cuya sombra nació el convento y la Torre Mocha, viejo torreón defensivo de origen medieval. La riqueza artística de la capilla de la Virgen y las demás con imágenes de los santos de la propia orden, así como la presencia de retablos y pinturas de los mejores artistas del momento, y cómo olvidarlo, las sucesivas restauraciones del convento, así como el hecho de que fuera centro de estudios, son indicativas de la riqueza de que dispuso el que fuera primer convento de la Recolección en la provincia Bética, separada ya de la de Granada en 1583.

28 Uno de los primeros titulares estableció en su testamento que se entregaran 4.000 maravedís, 4 fanegas de trigo y 4 fanegas de aceite a cambio de sepultura (bóveda) y dos misas semanales, una cantada y cuatro más rezadas para el día de Todos los Santos. La fiesta de los Fieles Difuntos, como ocurre todavía, se celebraba en la de Todos los Santos. 
La Virgen tenía un culto majestuoso, cuenta fray Ángel Ortega, que estaba servido por una comunidad floreciente y observante de sesenta religiosos ${ }^{29}$. Desconocemos a ciencia cierta la importancia de la devoción a la Virgen de Loreto en sus orígenes y cuándo se ensanchó a partir del núcleo original de Espartinas, Umbrete y Valencina a otros pueblos cercanos, si es que esto ocurrió antes de comienzos del XX. El manuscrito de Ledesma de comienzos del XVII que narra las leyendas de aparición de las más importantes advocaciones de Andalucía no cita a la Virgen de Loreto entre las grandes devociones andaluzas. Recordemos que tampoco lo hacían Villafañe y de la Fuente. Y ello a pesar de que como se dice en el prólogo, enumera todas aquellas de las que se tenía conocimiento en la ciudad de Sevilla, es decir aquellas cuya notoriedad había rebasado los límites locales y eran conocidas por su capacidad de hacer milagros en lugares muy distantes. La lista es larga y algunos de los santuarios han quedado actualmente fuera de la nombradía que tuvieron en otro tiempo, lo cual es prueba de que la fama de ciertas imágenes como milagrosas decae en el tiempo y a la vez surgen otras nuevas ${ }^{30}$. En el manuscrito tampoco se cita a la Virgen del Rocío, aunque un lector o bibliotecario se encargó de anotar, sin duda en fecha muy posterior: "Falta en este manuscrito tratar de la Virgen del Rocío (en término de Almonte), ya entonces antiguo en la fecha de este libro". Sin duda que existía desde muy antiguo la ermita de la Virgen de La Rocina, pero aún en el siglo XVII no había dado el salto a la fama que se producirá a finales del siglo XIX y sobre todo en el XX.

Ninguna luz arroja el documento de respuesta al cuestionario que, a finales del XVIII, el informante del geógrafo real Tomás López remitiera a los curas a través de los obispados. El cura de Espartinas resuelve la información de la villa de Espartinas en escrito de 1788 sobre Loreto con un escueto texto: "Tiene en su término un convento de religiosos franciscanos llamado Loreto, distante un cuarto de legua de la villa al Poniente" ${ }^{31}$. La ignorancia de la imagen solo puede explicarse por olvido, difícil en un cuestionario tan pautado, como era el del geógrafo real, o por mala fe del informador - piénsese en la competencia que se hacían entre sí curas y frailes- o, porque el icono mariano no tuviera mayor realce en aquella época, lo cual sería lo más plausible. Apoyo esta hipótesis en el hecho de que en los informes de los corresponsales de otras poblaciones donde existían imágenes marianas de gran devoción se refleja claramente la importancia de estas (López, 1989:82). Es cierto que en el manuscrito de fray Felipe de Santiago se narra su leyenda junto a otras quince, la mayoría de la actual provincia de Huelva y varias de ellas estrechamente relacionadas con la Orden Franciscana Recoleta, a la que pertenecían los cenobios de Loreto y La Rábida.

El siglo XIX, con su secuela de exclaustraciones y desamortizaciones, supondrá una etapa difícil para el convento del Loreto. El primer golpe vino de la mano de los franceses cuando el general Soult en 1810 cerró los conventos y dispersó las comunidades masculinas de regulares. El Provincial de la Observancia residente en el convento franciscano casa grande de Sevilla se retiró a Loreto y emigró a Portugal. Tras la salida de los franceses, se organizó la vida de la provincia de Andalucía, aunque el esplendor de otro tiempo nunca sería alcanzado de nuevo, y así pasó la provincia en 1808 de tener 1.544 religiosos a 469 en 1835 repartidos en 38 conventos. El convento de Loreto pasó de 60 a 14 religiosos.

El año de 1835, se decretó por el gobierno liberal la exclaustración de todos los frailes afectando a 23 religiosos de Loreto. La iglesia quedó en propiedad de la Mitra que nombró capellán a fray Miguel María del Toro, el conocido como Padre Miguelito, claustral de Loreto. Este fraile cuidó de la iglesia durante cincuenta años, preservó el convento y sus documentos del pillaje y mantuvo la actividad religiosa en torno a la Virgen. Además, la cercanía de la propiedad privada de la hacienda contribuiría sin duda a evitar el deterioro y la desidia que afectó a los lugares abandonados. Fue en este tiempo cuando la Virgen alcanzó más popularidad por el "carácter típico" que se imprimió a la fiesta del 8 de septiembre, la subsiguiente novena y las predicaciones por los pueblos. A la muerte del P. Miguelito, ocurrida en 1875, estuvo cinco días su cadáver expuesto sin señal de corrupción; en un día se contaron 464 caballos y 68 carruajes para ver el cadáver. El juez municipal, el párroco de Espartinas, el notario de Olivares y el médico de Villanueva certificaron que al enterrarse se encontraba en perfecto estado de conservación. Su hermano fray Juan del Toro, párroco de Umbrete, le sucedió en la capellanía.

29 A la imagen originalmente de candelero, le hicieron cuerpo de talla, respetando cabeza, cuello y manos. La efigie descansa sobre peana recubierta de plata a martillo, que se asemeja al tronco de un árbol en recuerdo de su aparición en la copa de un olivo. $30 \mathrm{El}$ manuscrito, titulado Imágenes de María Santísima Ntra. Sra. en esta ciudad de Sevilla y su reinado y distrito de Andalucía y Extremadura, donde están estos santuarios y algunas noticias de Sevilla y de su santa Iglesia recogidas por Joan de Ledesma, escribano público de Sevilla. Año de 1633, refiere la historia, leyenda de aparición y milagros de las principales advocaciones marianas de la ciudad de Sevilla y su arzobispado, muchas de las cuales se situaban en conventos de las órdenes religiosas masculinas. (Institución Colombina. Biblioteca Capitular y Colombina. Ms. 59-4-19).

31 No disponemos por haberse extraviado o por no haberse contestado de la información referida a la villa de Umbrete, jurisdicción civil y religiosa del Arzobispado, quizás por aquello de que "en casa del herrero cuchillo de palo". El manuscrito se encuentra en la Biblioteca Nacional y ha sido publicada parcialmente (López, 1989). 
La restauración de los franciscanos recoletos en Andalucía tuvo lugar en este convento, por lo que de alguna manera se considera la casa madre de los Menores de la Bética. Los frailes se reinstalaron en 1881 y para la reinauguración de la iglesia afluyeron vecinos de Espartinas, Olivares, Umbrete, Gines, Castilleja, Valencina y aún de Sevilla, conjunto de pueblos que configuraban el área de devoción más permanente de la imagen. El obispo auxiliar de Sevilla declaró en nombre del arzobispo, instalada la comunidad en Loreto y "establecida la clausura en la forma canónica" (Ortega, 1907: 65). La fiesta terminó con una comida ofrecida a las autoridades de Sevilla y alcaldes y jueces de la comarca. Componían la comunidad en ese momento 33 religiosos: 10 sacerdotes, 15 coristas o jóvenes profesos estudiantes y 8 hermanos legos; de los cuales 14 eran españoles y los demás franceses. Los nuevos religiosos se adaptaron al carisma de Loreto, que incluía penitencia, "apostolado evangélico muy popular" y la devoción a la Virgen titular. La misma nota de extranjeros y desterrados de Francia los hacía más simpáticos al pueblo, aunque poco después regresaron a su país. A partir de aquí empieza la difusión de los franciscanos recoletos por Andalucía, siendo Loreto la sede desde la que partieron muchos frailes, dado que en él estaba el Noviciado. Posteriormente en 1892, se restaura la provincia de Andalucía a los cincuenta años de haber sido expulsados por el decreto desamortizador.

La iglesia de Loreto fue hermoseada con mármol y se restauró el camarín, por ello la Virgen fue más conocida y tuvieron lugar una serie de acontecimientos y celebraciones promovidas por la jerarquía y las organizaciones paraeclesiales dignas de destacar; en 1886 el cardenal-arzobispo fray Ceferino González, puso por intercesora a la Virgen de Loreto, con ocasión de la epidemia del cólera morbo asiático, prometiendo una peregrinación general si la diócesis se libraba del mal. Acudieron 18.000 fieles y veinte pueblos dejaron sus banderas en el santuario como testimonio. En 1897 tuvo lugar la peregrinación de las órdenes terceras de Sevilla a la que acudieron más de 600 terciarios, a los que se unieron 2.000 fieles del Aljarafe en Villanueva. El 15 de mayo de 1904 se celebró el 50 Aniversario de la proclamación del Dogma de la Inmaculada. Acudieron al santuario los pueblos del Aljarafe con sus párrocos, congregándose unas 6.000 personas. Finalmente, el 7 de julio de 1906 el Loreto fue escenario de la fiesta de las Espigas, promovida por la Adoración Nocturna de la Diócesis.

Estos actos masivos dieron pie a la coronación canónica, distinción poco frecuente en aquella época, lo que suponía un reconocimiento pontificio a las imágenes de más amplia devoción ${ }^{32}$. La imagen de Loreto fue coronada en 1950 con ocasión de la declaración como dogma por Pio XII de la Asunción de la Virgen "en cuerpo y alma" a los cielos. El acto fue precedido por una misión mariana de los frailes franciscanos por cuarenta y tres pueblos del Aljarafe ${ }^{33}$. Impuso la corona el arzobispo de Sevilla, cardenal Segura, como legado pontificio, ante una multitud que algunos calculan en veinticinco mil personas, autoridades y alcaldes de la comarca. En 1959 el papa Juan XXIII declaró a la Virgen de Loreto, patrona del Aljarafe, con cuya ocasión la imagen recorrió en procesión itinerante toda la comarca, empezando por Umbrete que la declaró Alcaldesa Honoraria Perpetua permaneciendo un día en cada una de las poblaciones ${ }^{34}$. Al cierre de los actos acudieron el cardenal-arzobispo de Sevilla, los párrocos del Aljarafe y numerosos franciscanos. Con esta declaración sin duda se reconocía la influencia religiosa de la imagen de Loreto sobre la comarca, porque no se hubiese conseguido, si no hubiera existido esa presencia masiva popular que previsiblemente era heredera de la expansión de la devoción que realizara el padre Miguelito.

No obstante, pocas décadas después el santuario de Loreto reducía su influencia a los pueblos más cercanos a su emplazamiento: Espartinas, Umbrete y Villanueva del Ariscal. En el estudio antropológico llevado a cabo en 1984 en todo el Aljarafe se constata cómo su ámbito se había reducido: "La Virgen de Loreto es otra importante devoción venida a menos y cuyo origen se halla en la influencia de los franciscanos. Su patronazgo sobre el Aljarafe es más teórico que efectivo, contando sólo con la devoción de los pueblos más cercanos". Y es que no existe ningún patronazgo real y efectivo que unifique a toda la comarca; los títulos que detentan la Virgen de Loreto como patrona del Aljarafe, o del Verdeo en el caso de la Virgen de Cuatrovitas, son más oficiales que reales, pues ninguna de ellas alcanza con su área de gracia más allá de cuatro o cinco pueblos (Rodríguez, Villegas y Escalera, 1984: 496). El patronazgo real, que no oficial, del Aljarafe

32 Es de destacar que las primeras coronaciones de imágenes de la Virgen en la diócesis de Sevilla anteriores a 1950 fueron las de los Reyes (1904), del Rocío (1919), de la Antigua (1929) y de las Mercedes de Bollullos (1948), superando la cuarentena en la segunda mitad del XX y primeros años del XXI. Recuérdese que hasta 1953 no se creó la diócesis de Huelva.

33 Sin duda en la comarca a estos efectos se hubieron de incluir otros pueblos pertenecientes a la provincia de Huelva que algunos autores han incluido en esta comarca, pero de la diócesis de Sevilla. La diócesis onubense fue creada en 1953, siendo su primer obispo Monseñor Cantero Cuadrado.

34 Después de Umbrete, pasó a Benacazón, Bollullos de la Mitación, Almensilla, Palomares, Gelves, Huévar, Pilas, Aznalcázar, Sanlúcar la Mayor, Bormujos, Tomares, Mairena del Aljarafe, San Juan de Aznalfarache, Camas, Gines, Valencina de la Concepción, Salteras, Albaida, Olivares, Villanueva del Ariscal y Espartinas. En este caso 22 pueblos, algunos menos de los que aquí consideramos y bastantes menos sobre los que se hizo la misión con motivo de la coronación. 
le corresponde a la Virgen del Rocío, como veremos más adelante. La fiesta principal es la novena previa al 8 de septiembre, dedicada cada día a un pueblo, y la procesión por los alrededores, celebrándose a lo largo del año misas, bodas, bautizos y viacrucis. Umbrete en la fecha que le correspondía de la novena fletaba autobuses para trasladar al santuario a gran parte del pueblo, aunque la asistencia regular era bastante menor. Villanueva del Ariscal con ocasión de la fiesta de la vendimia en septiembre peregrina con San Ginés de la Jara hasta el santuario de Loreto (Rodríguez, Villegas y Escalera, 1984: 218, 434).

El santuario de Nuestra Señora de Loreto, situado en el corazón del Aljarafe, pudo ser de hecho la patrona real y efectiva de la comarca, pero no lo ha conseguido por diversas razones que expondremos. Cuando el antropólogo norteamericano William Christian (1976: 101) elaborara el mapa de los santuarios españoles y sus áreas de devoción en los años setenta adjudica al de Loreto un "área de gracia" que incluye un radio de dos a cuatro pueblos de los alrededores, que a su vez se superponía con el área de devoción del santuario del Rocío, con un radio de influencia muy superior. El santuario y la Virgen de Loreto y sus administradores los frailes franciscanos no consiguieron lo que estuvieron a punto de alcanzar, o quizás lo alcanzaron relativamente a finales del XIX y primera mitad del XX, ser símbolo religioso por antonomasia de todo el Aljarafe.

Algunos factores se nos ocurren como coadyuvantes para que la imagen no alcanzara esa meta o, en todo caso, de la disminución a un área modesta que representan sobre todo Umbrete y Espartinas. Vaya por delante que es un hecho comprobado que las devociones que despiertan los iconos religiosos crecen y se expanden, pero también se retraen lentamente hasta circunscribirse a una sola población ${ }^{35}$. La valoración de cada uno de los factores requeriría más información de la que disponemos en este momento:

a) El fuerte control que ejercieron los frailes sobre el icono sagrado y las fiestas, de forma que impidieron manifestaciones populares que suelen acompañar a las fiestas. A esta actitud restrictiva debió contribuir el hecho de que sin duda la emblemática casa de la Observancia franciscana (donde además existían estudios de Filosofía y Teología), coartara la necesaria expansión de los devotos de la imagen. Es significativo el hecho de que fray Ángel Ortega, en su Historia de la Imagen y Santuario (1907) diga que cuando la imagen tuvo más atractivo en la comarca fuera durante la capellanía del padre Miguelito por el "carácter típico" que imprimió a la fiesta del 8 de septiembre y que continuó la comunidad recién instalada con un "apostolado evangélico muy popular".

b) La crisis en las órdenes religiosas y en el clero en general en los años setenta coincidiendo con la preparación del Concilio Vaticano II, que tantas expectativas creó y tantas frustraciones generó. La confusión fue grande, pues mientras una parte del clero regular y secular, la más joven y comprometida, no veía la llamada religiosidad popular como una vía adecuada para la nueva evangelización acorde con los tiempos y con la pobreza del mundo, la jerarquía se aferraba a su defensa como tabla de salvación. Esto pudo llevar a cierto descuido de este tipo de manifestaciones, tan queridas por el pueblo llano, por parte de la comunidad franciscana, lo que debió ir en detrimento de la popularidad de la imagen de Loreto.

c) El desarrollo galopante de un fenómeno sociocultural y religioso como la devoción a la Virgen del Rocío a partir precisamente de la segunda mitad del siglo XX, apoyado en los siguientes datos: la ermita del Rocío contaba con un emplazamiento muy aislado, lo que exigía recorrer un largo camino que duraba varias jornadas y fuera del control social de los núcleos urbanos; una hermandad gobernada efectivamente por seglares y muy celosa de sus privilegios que con frecuencia la enfrentaba al clero; unos nuevos medios de difusión como la televisión y la radio, pero también el boca a boca que llevaron la fama de la Virgen y sus milagros y finalmente, por el paroxismo de sentimientos que se generan en la romería. El Aljarafe empezó a ser ganado por esta devoción, encontrándose algunas de las hermandades de la comarca entre las de más solera y antigüedad.

En la actualidad la fiesta principal de la Virgen de Loreto sigue siendo la del 8 de septiembre, a cuya novena varias poblaciones del Aljarafe acuden cada día, reafirmando así su patronazgo. Otras poblaciones, las más cercanas al centro espiritual van en romería en fechas distintas del año a festejarla. Fuera del ciclo festivo, al santuario llegan algunos fieles de edad más que madura de la capital y los pueblos a oír la misa dominical y confesar en la seguridad de que serán atendidos; asimismo, se celebran numerosas bodas, movidos por la devoción, pero también por la belleza del convento-santuario y su emplazamiento. De igual manera y debido a la tranquilidad y el recogimiento que allí se respira y del servicio que ofrecen los frailes acuden grupos a retiros y convivencias (Romero Meilán, 2006: 21-23). En la puerta del compás del cenobio aparece un cartel de aviso con el siguiente texto: "HORARIO. Mañana de 9 a 13 H. Tarde de 4 a 20 H. Nota: En caso de urgencia se atenderá siempre".

35 Son numerosos los casos de imágenes venidas a menos, por sólo citar algunos casos cercanos, valgan los de la Virgen de Gracia en Carmona que expandía su devoción en el s. XVI por la Vega y la Campiña sevillanas y Consolación de Utrera que la sustituyó y su fiesta alcanzó a ser la más numerosa de Andalucía occidental, decayendo en el XIX tras prohibiciones reales y la exclaustración de los Mínimos. 


\section{La Virgen del Rocío en el Aljarafe}

La Virgen del Rocío y su romería han cobrado importancia creciente en la geografía andaluza, especialmente en las provincias de Huelva, Sevilla y Cádiz, pero también fuera de ella a partir de los años cincuenta; con anterioridad era una romería circunscrita a unos pocos pueblos de La Marisma de uno y otro lado del Guadalquivir. La coronación canónica en 1919 que ya fue una prueba indicativa de su importancia supuso un punto de inflexión a partir del cual se iniciará un continuo ascenso, que se incrementó en el último tercio del siglo pasado y que ha continuado hasta alcanzar el número de ciento siete hermandades en 2008 y una afluencia de aproximadamente de un millón de romeros y visitantes en la romería de Pentecostés ${ }^{36}$.

En el Aljarafe igualmente ha cobrado gran importancia a partir de los años cuarenta del pasado siglo, incrementándose paulatinamente hasta alcanzar un alto de grado de devoción y participación que puede verse en múltiples manifestaciones por todos los pueblos del Aljarafe (Rodríguez, Villegas y Escalera, 1984: 219). En los días precedentes a la romería, la comarca se llena de cortejos romeros tanto de sus pueblos como de otros muchos que utilizan este camino para llegar al santuario del Rocío. El primer dato de la importancia que tiene el Rocío para todo el Aljarafe como festividad religiosa, pero también como ceremonial social y cultural, es que todos los pueblos salvo tres han creado hermandades o agrupaciones, siendo en algunos de ellos fiesta principalísima como en Villamanrique, Pilas, Gines o Umbrete.

La vinculación de la comarca con el Rocío empieza cronológicamente por los pueblos más cercanos a La Marisma, encontrándose dos hermandades de la comarca, Villamanrique, que es la más antigua y Pilas, nacida en el siglo XVII; Umbrete y Coria del Río que se crean en la primera mitad del s. XIX; Benacazón, Carrión, Gines, Olivares y Puebla del Río, surgidas en el primer tercio del XX; Espartinas, Sanlúcar la Mayor, Bollullos, Huévar y Aznalcázar creadas en el segundo tercio y Villanueva del Ariscal, Bormujos, Camas, Gelves, Almensilla, San Juan, Santiponce y Tomares en el tercer tercio del siglo; finalmente, Mairena y Palomares son ya del siglo XXI. Las de Albaida, Salteras y Valencina tienen estatus de asociaciones públicas, agrupaciones o hermandades no reconocidas por el ordinario, aunque en la práctica esto no tenga mayor importancia ${ }^{37}$. En síntesis, todos los pueblos del Aljarafe, salvo tres, tienen hermandad del Rocío, lo cual quiere decir que en uno de sus templos existe un altar donde recibe culto la imagen a través de su Simpecado. Puede decirse sin temor a exagerar que el Aljarafe es una de las comarcas con más fervor rociero desde hace mucho tiempo y si la presencia en el conjunto de la comarca es relativamente reciente -con la salvedad de Villamanrique y Pilas-, puede decirse sin exagerar que el Rocío es la romería del Aljarafe y que la virgen del Rocío es su patrona. En su ámbito tienen lugar algunos de los más emblemáticos actos de toda la romería, tal como el paso del río Guadiamar por el vado del río Quema en Aznalcázar o el paso por la población de Villamanrique de las hermandades, ambos actos declarados fiestas de interés turístico nacional de Andalucía.

Otros datos que ponen de manifiesto la intensidad con la que vive el Aljarafe la fiesta puede observarse recorriendo sus pueblos. Podemos ver azulejos de la imagen en las viviendas y edificios públicos, monolitos en las plazas, altares con los simpecados en sus iglesias, casas de hermandad, calendarios recordando los días que faltan para la romería y desde luego, los preparativos cuando se acerca la fecha de la romería. Porque el Rocío es sobre todo la romería de Pentecostés, aunque el calendario se ha ido llenando de otras celebraciones como el Rocío $\mathrm{Chico}^{38}$, la peregrinación anual de cada una de las hermandades en fecha pre-

\footnotetext{
36 Antes de mediados del siglo XX las coronaciones -imposición de una corona a una imagen de la Virgen- eran muy restringidas, exigían un proceso ante Roma que era largo y costoso, de ahí que solo algunas imágenes de cierta notoriedad lo consiguieran. A partir del Concilio Vaticano II esta potestad fue delegada en los obispos. Éstos han querido contentar a todos aquellos que tenían alguna razón para solicitarlo: una imagen que recibiera el fervor de una comunidad o una hermandad que esté dispuesta a arrostrar los gastos necesarios. También es explicable que haya sido utilizada como táctica evangelizadora y de acercamiento al sector más activo de la sociedad creyente, como son las hermandades y a algunas poblaciones. Alcanzar este reconocimiento para su imagen se ha convertido para las hermandades en una principal actividad. En la diócesis de Sevilla, que hasta el 1953 incluía Huelva, se han realizado 44 coronaciones desde 1904 en que lo fue la Virgen de los Reyes, hasta 2008, correspondiendo 3 a la primera mitad del siglo XX, 24 a la segunda mitad y 17 a los 8 años transcurridos del presente siglo (www.lahornacina.com/articuloscoronaciones. htm).

37 Las hermandades y agrupaciones rocieras del Aljarafe son las siguientes: Albaida del Aljarafe, Almensilla, Aznalcázar, Benacazón, Bollullos de la Mitación, Bormujos, Camas, Carrión de los Céspedes, Espartinas, Gelves, Gines, Huévar del Aljarafe, Mairena del Aljarafe, Olivares, Palomares, Pilas, Salteras, San Juan de Aznalfarache, Sanlúcar la Mayor, Santiponce, Tomares, Umbrete, Valencina de la Concepción, Villamanrique de la Condesa y Villanueva del Ariscal. Carecen de hermandad solo Castilleja del Campo, Castilleja de la Cuesta y Castilleja de Guzmán.

(www.hermandadmatrizrocio.org y www.rocio.com).

38 El Rocío Chico es el nombre de la fiesta votiva que Almonte prometió celebrar cada 19 agosto en su ermita; este voto fue ofrecido por las instituciones locales en 1813 en agradecimiento a la Virgen por haber evitado la operación de castigo que el ejército francés había preparado contra la villa.
} 
fijada, aparte de visitas familiares y de agrupaciones de diverso tipo que, especialmente los fines de semana, acuden a la imagen que mayor devoción despierta en el conjunto de Andalucía ${ }^{39}$. Como consecuencia de su situación geográfica, verdadera antesala occidental del santuario y aldea, las hermandades que proceden de Sevilla toman la ruta del Aljarafe, que tras pasar por varios pueblos y atravesar el Guadiamar por el Vado de Quema, se detendrán en Villamanrique, donde se produce un ceremonial que ha dado lugar a una gran fiesta, alcanzan la aldea del Rocío.

\section{El Vado de Quema en Aznalcázar.}

El río Guadiamar que divide los términos de Aznalcázar y Villamanrique antes de desembocar en el Guadalquivir es testigo de uno de los más señalados rituales cívico-religiosos que viven los rocieros que hacen el camino de Villamanrique por primera vez, el "bautismo" en el Vado de Quema. Es una ceremonia profana, pero con contenidos religiosos, puesto que de un ritual de iniciación se trata. Los "neófitos" deben ser "bautizados" por inmersión en las aguas del Guadiamar, el río del Aljarafe, antes de entrar en el territorio sagrado del camino del Rocío. Este Vado de Quema, toma su nombre de un cortijo que está situado en la margen izquierda. El lugar es paso obligado para gran número de Hermandades del Rocío. Cada año, cuando llega el mes de mayo se vive intensamente el ambiente rociero en este lugar, con gran júbilo y devoción y se ofrecen al visitante las más bellas estampas de esta popular romería. El Vado de Quema se ha constituido en uno de los lugares claves del peregrinar rociero.

El paso de las Hermandades del Rocío por el Vado de Quema tiene su origen en las primeras peregrinaciones de devotos a la aldea del Rocío, cuando incluso aún no se habían constituido las Hermandades como tales. La relación de Sevilla con el Rocío ha sido determinante en el crecimiento de la romería; difícilmente podría explicarse lo que ha llegado a ser esta devoción y romería sin la presencia desde muy antiguo de la las hermandades sevillanas. Así, ya en 1813 surge la Hermandad de Triana que peregrinó por primera vez en mayo de 1814. A esta Hermandad le siguió tiempo después la conocida como del Salvador, y recientemente otras tantas como Sevilla Sur, Cerro del Águila y Macarena, y pueblos de la provincia. El Vado de Quema es actualmente paso obligado para cincuenta y una hermandades y diez asociaciones rocieras, siendo el famoso Vado el protagonista varios días antes de la romería.

Este nuevo Jordán, como llaman muchos a este paso, constituye uno de los espacios y momentos más cantados y contados del camino porque está lleno de contenido emocional y de recuerdos para los romeros. Aznalcázar ha levantado un templete que simula una carreta de simpecado que incluye una imagen de la Virgen del Rocío. El paso de las hermandades por el Vado de Quema se produce los martes, miércoles, jueves y viernes antes del día de la fiesta de Pentecostés, resultando el jueves el día del máximo esplendor, pues cruzan el vado muchas hermandades de gran significación popular como Triana y Coria, que llegan acompañadas por miles de personas. Es por ello que los medios de comunicación tienen una cita obligada en este punto. Los momentos más emocionantes lo constituyen el paso de las carretas y carros de las hermandades con los simpecados, tiradas por yuntas de bueyes y mulas, a la que acompañan los peregrinos a pie y a caballo.

Este paso se ha convertido en una de las más bellas y representativas estampas del Rocío, por lo que los medios de comunicación se hacen eco de él cada año. Cuando la carreta está dentro del agua brotan cantos y rezos, y en ocasiones el "bautizo" de los que hacen el camino por vez primera. Es el momento más emocionante, la alegría embarga y se graba en la memoria de los iniciados. Es este uno de los muchos momentos inolvidables del Rocío, mezcla en partes desiguales, según la actitud de cada uno, de devoción y agradecimiento a la Virgen -la Señora como gustan llamarla los rocieros-, goce estético, emociones y placeres. Una vez que han cruzado el vado las carretas y carros que acompañan al Simpecado puede apreciarse la meritoria labor de los boyeros y carreteros dirigiendo a las yuntas en la bajada de la pendiente y posterior subida. El paso se hace en un horario de tránsito establecido, de tal forma que cada treinta minutos aproximadamente cruza una hermandad. Este "Paso de las Hermandades del Rocío por el Vado de Quema" fue declarado Fiesta de Interés Turístico de Andalucía el año 2002.

Una vez superado el Quema los romeros de la ruta sevillana que es la que sigue la mayoría de las hermandades del oeste y sur sevillano alcanzan Villamanrique de la Condesa. Este camino denominado de Villamanrique es el más conocido de todos. Las diferentes rutas que lo componen hacen, que solo la entrada en el Ajolí, puerta de acceso a la meta rociera -el santuario y la Virgen- sea el punto común a todas ellas. La ruta sigue hacia los pinares de Aznalcázar, en donde confluyen las hermandades que vienen de Marlo. La finca de San Diego y su ermita es otro enclave de esta ruta de la provincia de Sevilla. Estos caminos, junto

39 Aunque Andalucía no tiene una patrona oficial, si alguna advocación mariana sobrepasa los límites provinciales, y su área de devoción incluye Andalucía, aunque con distinta intensidad en su amplio territorio, ésta es la Virgen del Rocío (Rodríguez Becerra, 1989). 
con los que se incorporan por la Cañada Real de los Isleños, llegan al Vado de Quema, punto importante para las hermandades que lo cruzan, ya que, junto al paso del Guadalquivir, el paso por Villamanrique, la Raya Real y la entrada al Ajolí son los puntos más señalados de esta ruta. A partir de Villamanrique el camino hacia la aldea está marcada por otros puntos importantes como son: Hato Blanco, Gato, Cerro Tía Cana, Cancela del Urracal, Pozo Máquina, Raya Real, Palacio del Rey, Cañada Mayor, El Vicioso, El Pinto, Matasgordas, y otros.

En Villamanrique donde la primera hermandad recibe a todas las que siguen la citada ruta a la que se unen las que llegan por la Marisma, la junta de gobierno aguarda en la puerta de la parroquia con su simpecado el saludo de los peregrinos y la presentación de las hermandades, que se prolongará durante varios días con diversa intensidad. Esta ceremonia religiosa, pero laica, es formalmente protocolaria, pero también llena de emociones y buenos deseos. El protocolo entre hermandades juega un importante papel en las relaciones entre personas e instituciones que los romeros realizan con toda seriedad, conscientes de su importancia para el buen discurrir de una fiesta en que el camino juega un papel tan importante como la llegada. Esta ceremonia forma parte del complejo y amplio sistema ceremonial y de relaciones que constituye la Romería del Rocío, por supuesto para las hermandades que siguen este camino. La presentación en Villamanrique ha evolucionado hacia una verdadera fiesta, anticipo de la que tendrá lugar en la Aldea, porque están tamborileros, caballistas, banderines y estandartes de las hermandades arropados por los romeros, que siguiendo las reglas de buena educación y protocolo de las hermandades rocieras, se detienen ante la parroquia en cuyas puertas abiertas se sitúa la junta de gobierno de la de Villamanrique, y los bueyes con el simpecado se inclinan ante la primera hermandad de la Virgen del Rocío. Por los actos y valores tradicionales que allí se dan cita este "Paso de Hermandades" fue declarado Fiesta de Interés Turístico Nacional de Andalucía en 1999 ".

\section{Bibliografía}

Aguilar Criado, Encarnación, Las hermandades de Castilleja de la Cuesta. Un estudio de Antropología Cultural. Ayuntamiento de Sevilla, 1983.

Amores Martínez, Francisco, El Convento y Santuario de $N^{a}$. $S^{a}$. de Loreto en el Aljarafe sevillano. Estudio histórico-artístico. Sevilla, 1994.

Amores Martínez, Francisco, "Culto y fiesta en torno al Santísimo en los pueblos del Aljarafe de Sevilla (1510 - 1835)", en Religiosidad y ceremonias en torno a la Eucaristía, vol. I. Estudios Superiores del Escorial, Madrid, 2003.

Amores Martínez, Francisco, "El convento sevillano de Nuestra Señora de Loreto. Historia, arte y espiritualidad", en Cuatro siglos de presencia de los franciscanos en Estepa. Ayuntamiento de Estepa, 2007.

Angulo Íñiguez, Diego, Arquitectura mudéjar sevillana de los siglos XIII, XIV y XV. Ayuntamiento de Sevilla, 1983.

Burgos, Antonio, La Romería del Rocío. Ediciones Everest, Barcelona, 1974.

Carrasco Díaz, Manuel, Historiando el Rocío. Villamanrique de la Condesa, 1970.

Carrasco Díaz, Manuel y otros, El Rocío (Fe y alegría de un pueblo). 3 vols. Editorial Andalucía de Ed. Ariel. Granada, 1981.

Christian, William A., "De los santos a María: panorama de las devociones a santuarios españoles desde el principio de la Edad Media hasta nuestros días", en Temas de Antropología española (C. Lisón Tolosana, ed.), Madrid, 1976, pp. 49-129.

Comelles Esteban, Josep M., "Rocío”, Política y Sociedad, 12 (1993), pp. 149-I61

Cortínez Murube, Felipe, "Capítulo historial de la Asunción de Nuestra Señora en Sevilla", Anales de la Universidad Hispalense, I - III (1944).

\footnotetext{
40 Este camino lo realizan las siguientes Hermandades y Asociaciones: Villamanrique de la Condesa, Triana, Coria del Río, Umbrete, Benacazón, Gines, Dos Hermanas, Olivares, Puebla del Río, Espartinas, Sanlúcar la Mayor, Bollullos de la Mitación, Sevilla (El Salvador), Huévar, Aznalcázar, Villanueva del Ariscal, Lucena, Los Palacios y Villafranca, Écija, Bormujos, Camas, Las Palmas de Gran Canaria, Córdoba, Granada, Cabra, Málaga, Puente Genil, Jaén, Alcalá de Guadaíra, Marbella, Tocina, Gelves, Utrera, Almería, Sevilla-Cerro del Águila, Sevilla-Sur, Almensilla, Las Cabezas de San Juan, San Juan de Aznalfarache, Fuengirola, Osuna, Santiponce, Valencia, Mairena del Alcor, Carmona, Sevilla-Macarena, Málaga (La Caleta), Priego de Córdoba, Ronda, La Algaba, Murcia, Tomares, Palomares del Río, Morón de la Frontera, Moratalaz, Mairena del Aljarafe, Pozuelo de Alarcón, Santa Fe, Albaida del Aljarafe, Garrucha, Gijón, Montequinto, Brasil, Sevilla-San Pablo, Santander, Valencina y Salteras (http://www. ayto-villamanrique.es/rocio/index2.htm).
} 
Domínguez Ortiz, Antonio, "Santiponce y el monasterio de San Isidoro del Campo", en

Archivo Hispalense, 183 (1977).

Escalera Reyes, Javier, Sociabilidad y Asociacionismo: Estudio de Antropología Social en el Aljarafe sevillano. Diputación de Sevilla, 1990.

García Benítez, Antonio, Vírgenes, fratrías y banderías. Padilla Libros, Sevilla, 2002.

González Moreno, Joaquín, "Documentación sobre Oratorios de los siglos XVII y XVIII". Archivo Hispalense, 248 (1998).

González Polvillo, Antonio, Iglesia y Sociedad en la villa de Salteras durante el siglo XVI. Madrid, 1994.

González Polvillo, Antonio, La Virgen de la Oliva de Salteras. Historia, arte y devoción en los siglos XVI al XX. Ayuntamiento de Salteras, 2005.

Herrera García, Antonio, El Aljarafe sevillano durante el Antiguo Régimen. Diputación de Sevilla, 1980.

López, Tomás, Diccionario Geográfico de Andalucía: Sevilla, Editorial Don Quijote, Granada, 1989. Edición e introducción de Cristina Segur Graíño.

Márquez Fernández, Juan, "El origen histórico del Rocío", en Cuadernos del Aljarafe, 2 (1995).

Moreno Navarro, Isidoro: Propiedad, clases sociales y hermandades en la Baja Andalucía. La estructura social de un pueblo del Aljarafe. Siglo XXI, Madrid, 1972.

Murphy, Michael D. y González Faraco, Juan Carlos (coord.), El Rocío: análisis culturales e históricos: siete estudios y una bibliografía sobre la devoción rociera. Diputación Provincial. Huelva, 2002. Prólogo de S. Rodríguez Becerra.

Ortega, fray Ángel, Historia de la imagen y santuario de Loreto. Lérida, 1907.

Ortega Santos, Evaristo, De los carros de Torrijos a la romería actual. Sevilla, 1993.

Rodríguez Becerra, Salvador, Etnografía de la vivienda. El Aljarafe de Sevilla. Universidad de Sevilla, 1973

Rodríguez Becerra, Salvador, "La Romería del Rocío, fiesta de Andalucía”, El Folk-Lore Andaluz, 3 (1989), pp. 147-152

Rodríguez Becerra, Salvador, "La Virgen María en Andalucía. Aproximación a los procesos de creación, difusión e institucionalización de las devociones marianas", en Vírgenes, reinas y santas. Modelos de mujer en el mundo hispánico (D. González Cruz, ed.). Universidad de Huelva / Centro de Estudios Rocieros, Huelva, 2007.

Rodríguez Becerra, Salvador; Villegas Santaella, Antonio y Escalera Reyes, Javier, Informe etnográfico. Manifestaciones, expresiones y símbolos de la religiosidad popular en el Aljarafe sevillano, Sevilla, 1984 (inédito).

Romero Meilán, fray Bernardino, "Breve historia del Santuario de Nuestra Señora de Loreto y convento franciscano del mimo nombre", en Nuestra Señora de Loreto. Patrona del Aljarafe. Comunidad franciscana de Loreto, Espartinas, 2000.

Romero Mensaque, Carlos José, El Rosario en Sevilla. Devoción, rosarios públicos y hermandades (siglos $X V-X X I)$, Ayuntamiento de Sevilla, 2006.

Santiago, Fray Felipe de, Nuestra Señora de la Rábida. Edición del manuscrito: Libro en que se trata de la antigüedad del convento de $N^{a}$. $S^{a}$. de la Rávida y de las maravilla y prodigios de la Virgen de los Milagros (1714), Ayuntamiento de Palos, 1990.

VV. AA., Mairena del Aljarafe y la Hermandad de Nuestra Señora del Rosario. 375 años de historia, Sevilla, 1991.

VV. AA., La Romería del Rocío. Trabajos leídos en la sesión ordinaria celebrada el 2 de junio de 1933, Academia de Buenas Letras, Sevilla, 1934.

VV. AA., Nazarenos de Sevilla, Crucificados de Sevilla y Misterios de Sevilla, Ediciones Tartessos, Sevilla, 1997 - 1999.

Zurita Chacón, Manuel, Rocío: Camino de luz. Fotografías de Ramón León, Sevilla, 2005. 